\title{
Leadership Development for Latino Community Emancipation: An Integrative Approach in Social Work Education
}

\author{
Antonia Elizabeth Cordero \\ Lirio K. Negroni
}

\begin{abstract}
A primary goal of the social work profession is social justice advocacy for disenfranchised and oppressed communities such as the Latino community. In the context of this paper, leadership development for community emancipation relates to efforts that foster indigenous community leadership designed to procure political rights or equality for their disenfranchised or devalued populations. The paper reviews the literature on Latino/a leadership perspectives, leadership development trends, and best practices that serve as a compatible integrative Latino/a approach. The approach proposes that the process of Latino/a leadership development should be collective, culturally attuned, transformative, and community emancipatory. The authors present a model for students, alumni, and faculty that incorporates the approach through the use of three components: (1) Sustained institutional commitment, support, and resources; (2) Creation of leadership opportunities, mentoring, and modeling; and (3) Leadership efforts that foster community emancipation. The approach has been successfully employed for over 30 years in a Latino Project at a New England School of Social Work. Discussion of the model's components, a case scenario, considerations for replication of the approach, and future research will be offered.
\end{abstract}

Keywords: Latinos/as, leadership development, community emancipation, social work education

Leadership development is an important function for many fields and professional disciplines. Effective leaders are much needed and valued. The literature on leadership is broad and diverse, ranging from characteristics and types of leaders, skills, theories, and approaches to leadership development. Traditionally, leadership studies have been conducted in the private sector; however, because of surmounting social problems and the paucity of economic resources, studies have expanded to include leadership in public and community settings (McGonagil \& Reinelt, 2011). Consensus among leadership scholars about the primary characteristics of effective leadership include: someone who can influence, facilitate cooperation, inspire through their vision, demonstrate engagement, and interact and negotiate with others; in addition to possessing the ability to unite, encourage, and energize individual followers, groups, organizations, or communities.

There are two distinct aims in the field of leadership development: leadership as a vehicle to achieve organizational management objectives, or a collaborative process between leaders and communities to achieve a change in targeted social problems

\footnotetext{
Antonia Elizabeth Cordero, Ph.D., and Lirio K. Negroni, Ph.D., are Associate Professors in the School of Social Work at the University of Connecticut in West Hartford. The authors would like to acknowledge The University of Connecticut School of Social Work students, alumni, faculty, and the Greater Hartford Connecticut Latino Community for their invaluable contributions to the Puerto Rican/Latino Studies Project.
} 
(McGonagill \& Pruyn, 2010). The goal of leadership as a collaborative process for social change is consonant with the mission and values of the social work profession and education. Both the National Association of Social Workers (NASW) and the Council on Social Work Education (CSWE) have identified leadership development as essential for the profession to meet its mission, goals, and commitment to equality and social justice. NASW's commitment to leadership development is reflected in the 10 social work imperatives adopted for the 2010-2020 decade (NASW, 2010). In 2008, CSWE created a Leadership Institute to promote future leaders in social work education, higher education, and the social work profession. Also, every year during CSWE's Annual Program Meeting, two major events are celebrated: the Leadership Scholars in Social Work Education Program to train and mentor future leaders, and the Leadership Networking Reception to support, encourage, and recognize new leadership in the social work profession (CSWE, 2012). Social work education identifies leadership competence as: (1) team building, (2) conflict resolution, (3) assessing personnel and maximizing productivity by recognizing system influences on individual and organizational functioning, (4) building professional relationships, (5) advocacy, and (6) managing group processes (Sheafor, 2006).

A primary goal of the profession is social justice advocacy for disenfranchised and oppressed communities. While there is inherent strength and resiliency within these communities, there remains a need to promote social justice to ensure their collective well-being, political and social emancipation (Caravalho \& Kayama, 2011; Farooqui, 2012; Freire, 1974; Giroux, 1992; Omotoso, 2010). In this context, community emancipation is viewed as any effort to procure political rights or equality for disenfranchised groups. Farooqui (2012) proposes education as the key to community emancipation. According to Omotoso (2010), “....any form of education that does not give birth to emancipation is unjust. The implication is justice should be a summation of education and emancipation” (p. 228).

This article focuses on leadership as a response to the Latino community's history of encountered invisibility, oppression, and discrimination in the United States; and their struggle to achieve fair treatment and emancipation. The term "Latino/a" is used to refer to the diversity of over 19 countries or nationalities that make up the Latino population. Latinos are usually statistically overrepresented in experiencing many socioeconomic challenges. Despite efforts to improve these inequities, socioeconomic conditions of many Latino communities continue to worsen. As a result, there is a mounting call for more Latinos/as who can take on leadership positions in education, program development, community organizing, community development, research, and policy that will initiate the changes needed to enhance the quality of life for Latino communities while validating and affirming their cultural identity, values, and strengths.

The following paper presents an integrative leadership development approach that has been employed for over 30 years in a Latino Project at a New England School of Social Work. Prior to a discussion of the leadership development approach, a demographic profile of the Latino/a population is presented, followed by a literature review on educational Latino/a leadership perspectives, general leadership development trends, and best practices that serve as a compatible integrative Latino/a approach. 


\section{Demographic Profile Latinos/as}

Latinos/as are ethnically diverse and represent $16.7 \%$ of the population of the continental United States (U.S. Census Bureau, 2011a). They represent the nation's largest minority group. Their size is expected to triple and account for most of the nation's population growth from 2005 through 2050 (Pew Research Center, 2008). Latinos/as are younger than any other group in the continental United States -1 out of 3 is under the age of 24 (Pew Research Center, 2008). The majority of continental U.S. Latinos/as speaks Spanish at home: 56\% speak only Spanish, 26\% speak Spanish and English equally, and only 18\% speak English (US Census Bureau 2011b). While Latino/a poverty rates are higher (U.S. Census, 2001b), educational attainment and average earnings are lower than other groups (U.S. Census Bureau, 2011c). Latino workforce participation is larger than other groups (U.S. Department of Labor, 2011). As a commonwealth of the United States, the island of Puerto Rico contains an additional 3.7 million U.S. Latino/a citizens who are not counted in the census of continental Latino/a residents (U.S. Census Bureau, 2011d). The above profile characterizes Latinos/as as the largest, youngest, and fastest growing U.S. population. Despite having the highest work force participation, they have the lowest college attainment and average earning rates. As a population they are ethnically diverse, primarily Spanish or bilingual speakers. Thus, the above profile suggests that the ground is fertile for more Latinos/as to emerge as leaders who can address the socioeconomic needs of their communities.

\section{Literature Review}

\section{Latinos/as Educational Leadership Perspectives}

An increased commitment to Latino/a leadership development is prevalent among numerous organizations and groups in the United States. The majority of these development opportunities have an educational leadership focus. It is widely recognized that increasing the number of Latinos who successfully pursue associates, bachelors, graduate, and professional degrees is one of the most important and complex challenges for American colleges and universities (Chapa \& De la Rosa, 2006; Davis, 1997; Leon \& Nevarez, 2007; McWhirter, Torres, Salgado \& Valdez, 2007; Miller \& Garcia, 2004; Perna, 2006).

The persistence of Latino educational underachievement and underrepresentation in higher education has been reported in studies since the 1980s (Pachon \& Moore, 1981, Post, 1990; Chapa \& De la Rosa, 2006; Cooper \& Lious, 2007; Deil-Amen \& Turly, 2007; Golderick-Rab, Carter, \& Wagner, 2007; Louie, 2007; McWhirter et al., 2007; Oliva, 2008; Perna, 2006; Teranishi \& Briscoe, 2006). According to Oliva (2008), some scholars who study limited college access and success for Latino students, focus their research on individual-level factors such as students' academic preparation, motivation, college-choice process, and presumed student or family deficiencies. Nonetheless, there are studies that show a correlation between Latino student college access and performance and the broader external social issues affecting them, including immigration status (Cabrera \& Nasa, 2000; Erisman \& Looney, 2007; Nunez \& Carroll, 1998; Oliva, 2008; Perna, 2006; Saenz, Hurado, Barrera, Wolf, \& Yeung, 2007). Oliva (2008) 
recommends that there should be a shift away from the examination of Latino/a student and family deficiencies as related to college outcomes, and toward a holistic and systematic examination of their needs using a culturally appropriate lens.

Bordas (2001) adds the notion that effective leadership with Latinos/as is a collective, people-oriented view that grows out of Latino/a history and core values, and is responsive to the challenges Latino communities face today. Some of the core values that shape the collective Latino/a identity are: Familismo, Personalismo, Respeto, and Confianza (Bordas, 2001; Cordero \& Negroni, 2009; Mogro-Wilson, 2011; Negroni-Rodriguez \& Morales, 2001). Latino communities measure leadership actions through the lens of these core values (Ballesteros, 2007; Davis, 1997; Rodriguez \& Villarreal, 2001). Familismo is a commitment to upholding family values and supporting the integrity of the family unit. The family unit often extends beyond that of the nuclear family. Personalismo is an intrinsic value in establishing cooperative and personal relationships. Respeto is displaying social esteem and respect for an individual. Elders and children, in particular, are highly regarded and socially esteemed. Confianza is the process of establishing social intimacy and trust (Cordero, 2008). As Bordas (2001) states when describing effective cultural value-oriented Latino/a leadership:

Trusted Latino leaders are regarded as part of 'the family'...Unlike cultures that emphasize individualism, Latinos emphasize 'we', belonging and to group benefit... One of the roles Latino leaders play is being a trustee of their community's future and the guardian of the children (p. 119).

Personalismo does not mean that the individual takes precedent over the family, the group or community. Latino [leaders] are expected to respect and value the individual [student] in a collected context of the family or community. This establishes confianza (trust) and makes strong personal relationships. Centering on personal relationships means [the leaders is] spending more time building rapport...It also means lifting the veil of professionalism and allowing people to get to know the leader as a real-life person (p. 124).

Ballesteros (2007) prescribes that, among mainstream societies that diminish the value of differences, Latinos/as are compelled to preserve their rich cultural heritage; and, accordingly, leaders in educational institutions need to affirm Latino/a students' cultural pride on campus, and support course work on multiethnic/multiracial content, while promoting cultural exchanges with Spanish-speaking countries. Kane's (1998) and Perna's (2006) research findings support the need to evaluate and attend to student issues in a culturally appropriate manner rather than by using a standard approach. "Identifying what works for Latino/a students in higher education is an important step to reach our national goals of degree completion, a highly competitive workforce, and civic leadership" (Excelencia in Education, 2012, p. 6). Participation in university-sponsored Latino/a student organizations provides a vehicle for students to have their first exposure to the work of community leaders (Davis, 1997). In sum, scholars propose that more focus should be on the strengths of students, their families, and their communities in a culturally appropriate and effective manner (Ballesteros, 2007; Bordas, 2001; Davis, 
1997; Molloy \& Elis, 2006; Negroni-Rodriguez, Dicks, \& Morales, 2006; Oliva, 2008; Ramirez, 2006).

With greater acceptance of new qualitative methodologies, and a stronger presence of minority scholars studying college access and success for underrepresented students, other questions are being asked and more culturally responsive findings are being produced regarding what works, and what does not, with Latino/a students to facilitate their development as leaders (Collins, Weinbaum, Ramon, \& Vaughan, 2009; Miller \& Garcia, 2004; Oliva, 2008, Ramirez, 2006). In addition, due to the socioeconomic needs of surrounding Latino communities, there is an increased demand for social work leaders who can collaborate with these and other Latino communities throughout the nation.

\section{Trends in Leadership Development}

Leadership has disparate definitions based on its particular meaning to individuals, organizations, or communities. Bennis in his early work, Leadership Theory and Administrative Behavior: The Problem of Authority (1959), observed that "probably more has been written and less known about leadership than about any other topic in the behavioral sciences" (Hubbard, 2005, p. 4). A review of the literature indicates that the consensus among scholars in the field is more likely to focus on qualities, functions, and best practices in leadership development.

Since Burns' (1978) seminal book on leadership, scholars in the field have defined and ascribed the goals of leadership in many ways (Ballesteros, 2007; Bass, 1990; Bennis \& Nanus, 1985; Foster 2005; Henderickson, 1989; McGonagill \& Reinelt, 2011; Northouse, 2009; Ramirez, 2006; Rodriguez \& Villarreal, 2001; W. K. Kellogg Foundation, 2004). In a study of leadership development trends in the United States, McGonagill and Reinelt (2011) encapsulate the following leadership qualities, functions, and development trends:

- Effective leaders can influence and manage followers or facilitate a collaborative process of mutual interests with a group or community. Leadership abilities are shaped by personal qualities and include the process of personal growth. This growth enhances their understanding of the world's complexities and deepens their ability to come up with creative actions and options (Joiner \& Josephs, 2007).

- Ethics are recognized as an important element of leadership development because it takes into account social responsibility (Collins, 2001; Greenleaf, 1977; Kellerman, 2004; Senge, Smith, Kruschwitz, Laur, \& Schley, 2008).

- Leadership functions are viewed within the context of activities versus roles. Successful leadership outcomes result from leaders' participatory activity with others and their capacity to cultivate or identify leadership qualities in others; rather than their vested authority and delegation to others.

- Leadership development has a dual emphasis on the individual and the system. There is equal importance in the development of individual leadership and the 
creation of an organizational culture where, in the absence of official leaders, basic leadership tasks are enacted and carried out (Hubbard, 2005).

- Contemporary expansion of leadership development includes promotion of leadership networks that forge collaborative alliances among leadership groups to address complex multi-socioeconomic problems (Gauthier, 2006; Jordan, 2006; McKensie et al., 2008; Senge et al., 2008).

- Eastern and indigenous traditional leadership perspectives have been included in order to address social justice inequities and access to underrepresented groups (Adams, Bell, \& Griffin, 2007; Bordas, 2001; Center for Ethical Leadership, 2009; Griffin \& Ouellett, 2007; Ramirez, 2006).

\section{Best Practices in Leadership}

In the review of the literature, four areas emerge that the authors consider essential practices in Latino/a leadership development.

Collective leadership. McGonagill and Reinelt (2011) maintain that while much of the research on leadership qualities and development have been historically studied in private sector settings, recent work has begun to study leaders in public and community settings. They found that innovative leadership development programs in public and community settings produce individual leaders within the shared context of organizations, communities, or fields for a variety of reasons:

- Developing leadership one person at a time often requires more than what a single leader can achieve and it is also too slow for achieving the scope and scale of leadership needed to transform communities and influence policy (Enright, 2006).

- Developing teams of leaders, representative of the cultural context of their communities, can help them to support each other and validate their cultural realities in ways not supported by mainstream organizations (Enright, 2006).

- Communities full of leaders enable more shared leadership as people assume civic leadership roles as their interests, needs, and circumstances change (Ahsan, 2007).

Leadership is a communal relationship, one that occurs within a community of believers, representing a combination of ideas that are shared and transferred between leaders and followers (Foster, 2005). Foundations are increasingly investing in collective and network leadership efforts that address specific community organizational needs or social problems (Hubbard, 2005; Jordan, 2006; Northwest Area Foundation, 2006; Plastrik \& Taylor 2010; The California Endowment, 2006; W. K. Kellogg Foundation, 2006). In short, effective leadership perspectives develop collective and collaborative relationships of leaders, within and outside of the community, that promote an exchange of ideas to create a shared communal vision.

Culturally-attuned Leadership. With the wave of interest in organizational culture during the 1980s, there came a new leadership perspective that merged leadership with 
organizational culture (Schein, 1985). As early as 1989, Henrickson believed that while recognizing the importance of the leadership process, transformational leadership was still failing to effectively integrate the importance of the leader-follower relationship. He believed disconnecting leadership from management and somehow integrating it with culture could provide important and fresh perspectives on the concept of leadership; asserting that it is not possible to effectively understand the nature of leadership without applying a cultural model (Henrickson, 1989) or a culturally syntonic approach (Manoleas \& Carrillo, 1991).

Current scholars believe that diverse, culturally-inclusive learning circles are a microcosm for working across differences and learning first-hand how to prepare individuals and groups to lead collectively with others whose cultures and practices differ from their own (Foster, 2005; Meehan \& Reinelt, 2006; Reinelt, Yamashiro-Omi, \& Meehan, 2010). The Leadership Learning Community (2010) views leadership as a shared, relational process that is fundamental to many cultures even though the dominant American model of leadership is deeply rooted in individualism. Some scholars argue that if we add diverse perspectives and equity-based leadership approaches to status-quo leadership practices, educational leaders may be able to transform leadership practices and improve educational outcomes for larger numbers of culturally and linguistically diverse learners at every educational level (McKensie et al., 2008; Tooms \& Boske, 2010). To summarize, leadership development perspectives need to be culturally-attuned to the populations or communities they address.

Transformative leadership. Foster (2005) attributes the perspective of transformational leadership to Burns (1978) and describes it as the ability of individuals to envision new social conditions and to communicate these visions to followers, requiring leaders to engage with followers from higher levels of morality. Burns (2003) views leadership on a moral and value-driven basis, not as simply a managerial tool. He claims that, "the transforming leader looks for potential motives in followers, seeks to satisfy higher needs, and engages the full person of the follower" (Burns, 1978, p. 4). The outcome of this leadership style is a mutual relationship that changes followers into leaders, and leaders into moral agents. The notion of moral leadership is a means for leaders to take responsibility for their leadership and seek to meet the needs of the followers (Foster, 2005). Transformative leadership "raises the level of human conduct and ethical aspiration of both the leader and led, and thus it has a transforming effect on both” (Burns, 1978, p. 20).

Bass and Riggio (2006) broaden the definition to include: “...leaders (that) help followers to grow and develop into leaders by responding to individual followers' needs, empowering them and aligning the objectives and goals of the followers, leader (s), and the larger organization.” (p. 3). In their discussion about educational reform, Rodrigues and Villareal (2001) propose that transformative leaders will be confronted with the task of facilitating the thinking of diverse stakeholders whose culture, values, and beliefs have not been acknowledged or appreciated; and that the leaders will need to foster a climate of interdependence, relevance, and shared accountability. Therefore, leadership perspectives need to promote the development of equitable relationships between leaders 
and followers that transform their efforts to serve in the best interests of devalued and underrepresented communities.

Emancipatory leadership. Transformative practices, which change social structures and forms of community, require that leadership be critical of current social arrangements, and that this critique be aimed at more emancipatory types of relationships (McKensie et al., 2008). Foster (2005) ascribes the outcome of emancipatory relationships as "the gradual development of freedoms, from economic problems, racial oppression, ethnic domination, the oppression of women and so on, each of which has its own heroes and heroines: [Eleanor] Roosevelt, [Winston] Churchill, [Mahatma] Ghandi, [Martin Luther] King, [Susan B] Anthony are just some examples” (p. 33). Emancipatory leadership, however, demands more than the qualities of enlightened individuals. The idea that leadership emancipation occurs within a community suggests that leadership ultimately resides in the community itself (Foster, 2005).

Some scholars in the field of educational leadership development believe in a dynamic leadership process that focuses on how individuals and groups are connecting, organizing, thinking systemically, bridging, and learning to mobilize action on the scale needed to address socioeconomic inequities and injustices (Foster, 2005; Gauthier, 2006; Jordan, 2006; McKensie et al., 2008). Consequently, emancipatory leadership perspectives need to foster indigenous community leadership designed to gain political rights or equality for their respective disenfranchised groups. Davis (1997) contends that the process of leadership by nature is self-perpetuating; and part of the leader's work is involvement in the community that develops and mentors new leaders in skills development, participation in community activities, and an ongoing commitment to community improvement.

In summary, leadership development is no longer a process of whom to recruit for leadership programs, but, a field that enables learning to identify and support leadership efforts that are collective, culturally-attuned, transformative, and emancipatory. A crucial element of this leadership development process is the location of a community or region where there is a need for social change. Latino/a college attainment and improved socioeconomic conditions for Latino communities are examples of a location and need. In other words, an effective leadership development process is comprised of the identification of individual, organizational or networks of leaders vested in a collaborative emancipatory relationship with specific communities or regions to tackle their need (social problems) (Brabeck, Walsh, \& Latta, 2003; Annie E. Casey Foundation, 2006; Leadership Learning Community, 2010; W. K. Kellogg Foundation, 2004). The above best practices are integrated in the leadership development model that is presented in the following section.

\section{The Leadership Development Model}

The model presented in this paper has been implemented by the faculty members of the Puerto Rican and Latino Studies Project (PRLSP) at the University of Connecticut School of Social Work. A description of both the school and the Project precedes the presentation of the model. In addition, a case scenario depicting the development of a 
Project Latina leader, and examples of Project community emancipation outcomes are offered.

\section{The School of Social Work}

The University of Connecticut which hosts the School of Social Work is a land grant state institution. The School of Social Work has an enrollment of more than 400 students and offers both masters and doctoral degrees in social work. By the academic year 20122013, the school had a dean and two associate deans, 27 full-time faculty members, and 38 full- and part-time staff employees. Nine faculty members were representatives of different ethnic groups: two African-Americans, one Jamaican, three Puerto Ricans, one Bolivian, one Peruvian, and one African-American/Puerto Rican. Seven members of the professional staff were either Black or Latinos/as. During that 2011-12 year, the total incoming student population was 179, and the ethnic student enrollment was 14 Latinos/as, 49 African-Americans, and 4 Asians.

\section{The Latino Project}

In the early 80s, a group of Latino/a faculty and alumni, concerned with the lack of Latino/a representation in social work, developed the Project. Since its inception, the Project 's mission has been to: 1) prepare social workers to competently serve the Latino community by advocating and promoting change and 2) advance knowledge about the strengths, challenges, and resources of Latino/a populations and communities. The Project, initially funded by the National Institute of Mental Health (NIMH), provided financial support for 10 student scholarships, 2 faculty positions, and clerical support. After the NIMH funding ended, the University institutionalized the Project by funding the two faculty positions and increasing financial aid support for Latino/a students in the graduate social work program. In addition to the traditional academic responsibilities, the Project's faculty is involved in Latino/a leadership development as part of its commitment to the profession's mission and New England communities.

Most of the school's Latino/a students have been born and/or raised in the United States. The rest have emigrated from Latin American countries or migrated from Puerto Rico to pursue graduate education. In the last 10 years, an estimated 300 Latino/a students graduated, creating a difference in the Latino/a workforce of Master Social Workers. In addition, within the School of Social Work's doctoral program, currently celebrating its 10th anniversary, there has been one Latina Ph.D. graduate and four doctoral Latino/a students in different stages of their doctoral studies. Over 30 years, as a result of the Project's efforts, many graduates, particularly Latino/a graduates, have gone on to serve in leadership roles promoting collective collaboration with Latino communities and organizations. Project Latino/a graduates, acting in the capacity of practitioners, administrators, policy makers, researchers, educators, deans, judges, commissioners, CBO executives, and elected public officers, including the city's mayor, have had leadership impact in institutions, organizations, and agencies serving Latino communities, thus contributing to community emancipation. The Project recognizes the importance of quantifying the contributions of its Latino/a alumni and is currently in the 
process of tracking this data for future publication. The Project is one of the few projects of its nature in schools of social work in the United States.

\section{The Leadership Development Model}

Social work education prepares professionals to pursue social justice for underrepresented populations, foster socioeconomic equity, and political empowerment for devalued communities. As is born out in the literature, fostering emancipatory leadership does not occur in a vacuum. The authors propose that for the process of collective, culturally-attuned, transformative, and emancipatory leadership development to occur in a higher educational institution, a model with the following components should be present: (1) Sustained institutional commitment, support, and resources; (2) Creation of leadership opportunities, mentoring, and modeling; and (3) Leadership efforts for community emancipation. It is through the interaction of these three components that a collective, culturally-attuned, and transformative leadership process emerges, and, in turn, community emancipation takes place.

Institutional commitment, support, and resources. The higher education institution must be committed to leadership development. This commitment should be reflected by the presence of a supportive infrastructure, policies, and regulations that promote leadership development opportunities for students and faculty, and involvement in community partnerships that promote community emancipation. For example, it is only through the school's sustained commitment that the Project faculty continues to grow in its leadership development objectives, particularly in times of economic adversity. The Project has increased from two to five faculty members, four full-time tenured Latina members, and a recently hired full-time tenure-track member. Through the years, the School's cultural commitment and support has been a key to the Project's success in student and faculty recruitment, retention, and faculty tenure attainment.

In addition, as the Project has expanded, the school's administration has supplied an equipped office, a web page, and staff support to help with annual and special program events. Also, the school provides funding for the Project to annually host various student and community events that foster leadership encounters and networks. This support is essential for leadership development opportunities to be created and leadership efforts to be implemented in the community to advance their emancipation. This academic year, the Project hosted six events for Hispanic Heritage month and plans for an over 30 year Project anniversary celebration, which will include acknowledgement of the Project's founder and past Latino/a school alumni.

Creating leadership opportunities, mentoring, and modeling. As noted, the school's community is composed of students, faculty, staff, and alumni. Leadership development efforts at the school involve all of these sub-groups and reflect the school's commitment to leadership as a competence and tool for community emancipation. These efforts promote needed personal growth, an increased sense of social responsibility, along with participatory activities. The Project has created an infrastructure for leadership development that has contributed to the growth of a leadership culture; ultimately creating the Project's Latino Community Milieu. Leadership development occurs within 
the context of faculty mentoring and modeling leadership skills and roles to new faculty. Faculty also co-participates in different community efforts. These leadership opportunities are collective, culturally-attuned, and transformative. At the end of this section, a case scenario is presented as an example of how leadership opportunities are provided within the Project's community milieu.

Faculty remains alert to recognize leadership potential in students. Opportunities for these discoveries occur in the classroom, through advisement, and by observing student participation in different school organizations and events. Once leadership potential is assessed, mentoring relationships allow for a process of validation, orientation, and encouragement to take place. Mentoring is a process by which more experienced and knowledgeable individuals (mentors) act as guides, role models, teachers and supporters of less experienced individuals (mentees) (Luna \& Prieto, 2012). Mentoring can help mentees develop a stronger sense of competence and identity, and can help them to cope with different stressors associated with their roles and responsibilities in life (Bordes \& Arredondo, 2005). A factor that facilitates the development of these relationships is the notion that mentors and mentees have many characteristics in common. For example, having the same ethnicity can provide role modeling, cultural affirmation, pride (RiveraGoba \& Nieto, 2007), and the meta-message that advancement as a Latino/a is possible (Rojas-Schwan, Negroni, \& Santiago, 2012, p. 6). This is the case within the school's Project.

The work done by the Latin American Student Organization (L.A.S.O.) is an example of how leadership opportunities, mentoring, and modeling take place. A Project faculty member serves as the advisor, in collaboration with the Director of Student Services, to coach and mentor L.A.S.O. students who take on leadership positions in the organization. Usually two students perform as co-chairs and in that leadership role they learn to 1) assess and represent Latino/a students' concerns, 2) coordinate student events of particular need and interest to the Latino community, 3) recruit and engage students, alumni, faculty and community residents in the L.A.S.O. activities, and 4) collaborate with the Project on events and activities of mutual interest. Throughout the year, students observe Project faculty engaged in similar leadership roles, which supports Davis' (1997) claim that Latino student organizations serve as a central role in the emergence of Latino/a leadership as a vehicle through which young people can begin the leadership process.

Another example of leadership opportunities are the field placement internships offered through the Project. This year the Director of the Project is a field instructor for two Latina MSW students, a community organization, and an administration major. Their field assignments and activities help promote the Project's engagement and collaboration with Latino community constituencies within the school and outside community. Some examples include, working on a grant to support community-based research activities; coordinating the school's Hispanic Heritage Month activities; and providing education through a community radio program. In these activities, student interns have the opportunity to be mentored and observe faculty modeling leadership skills to effect change within the local community. 
A third example pertains to research scholarships that are given to two students enrolled in a Travel and Study course to Puerto Rico. The course encourages students to examine social work practice that employs a humans rights and social justice lens. Students submit a proposal for a research project about health disparities in Puerto Rico. The two scholarship recipients present the findings to the university community and community-based organizations in the area. A previous community research project, supervised by a Project faculty and a practitioner, led to the creation of a video about the social and health inequities created as a result of the bombing in Vieques. The video is available online as an educational tool to raise awareness of human rights violations, health disparities, and the need to advocate for social justice on behalf of Puerto Ricans living in Vieques. As a result, students developed leadership skills necessary to collaborate and support the Vieques community emancipation process.

As with the previous example, Project faculty facilitate leadership opportunities and mentoring of leaders in different developmental stages of students' professional development, even after graduation. As Latino/a social work alumni, Project faculty continue to enhance leadership skills by helping them to become role models to those who are in earlier stages of their professional development. One example is the state's chapter of the NASW Latino/a Network Mentoring program. A network of Latino/a chapter NASW members, supported by Project faculty, coordinates and recruits seasoned Latino/a professionals, many who are Project alumni, to mentor Latino/a graduates transitioning from school to professional social work employment.

The following case scenario describes the development of a Latina leader. It shows how the Project's community milieu led this individual to become an agent of change and emancipation within the Latino community. Olga was a bright first generation Puerto Rican student and the first person in her family to pursue graduate education. Prior to her arrival to the school, she had not visualized her potential as a leader, nor did she have leadership role models in her family. But, the seeds of her leadership potential were planted at the undergraduate level, where she was supported and culturally validated by her educational institution. A Latino colleague, who was an MSW alumnus and member of the Project, referred Olga to one of the Project's Latina faculty; who in turn, oriented and guided her during the application process. Upon her acceptance to the MSW program, the Director of Student Services and the Project faculty reached out to Olga to welcome her and connect her with other students. Olga began the MSW program in a culturally holding environment, where her cultural identity and values were affirmed and appreciated.

Motivated and inspired by the leadership of the Project Latina faculty, Olga hoped to "be a leader like them to help in my community." Mentored by the Director of Student Services and the Project faculty, Olga agreed to become L.A.S.O. co-chair. As co-chair, she also joined a community-university partnership effort, led by a Project faculty member, to plan a statewide youth conference; learning from her collaborations with other senior community social workers involved in this community-university partnership endeavor. As a result, her contributions to these activities were credited towards her field internship requirements. 
Olga joined the state's NASW chapter Latino/a Network Mentoring program to prepare for transition to her social work career. After three years in her first position in a youth services agency, she became supervisor and developed several grant-funded programs. As an alumnus, she remained involved in the Project by supporting social action efforts and providing voluntary professional presentations. She asserts that the modeling and mentoring of other Latina faculty motivated her to pursue a doctoral education. Project faculty mentored her through her years as a doctoral student. As part of her dissertation, she founded a grassroots movement in a local community to support policies that benefit immigrant families. Her research also explored the connection between acculturation and family relationships.

As a seasoned and nationally recognized Latina social worker and educator, her contributions have advanced different community advocacy actions and increased awareness of the importance of cultural sensitivity and competence. She has recently accepted a new position in Washington, D.C. to conduct national community research examining the challenges faced by Latino/a immigrants. She is currently a consultant to the United States Department of Human Services and maintains involvement with the Project.

During her leadership journey, Olga went through both personal and professional transformation, and the reaffirmation of her cultural identity and pride. She engaged in leadership efforts that were collective, culturally-attuned, transformative, and emancipatory. As a testament to the Project's community milieu, she continues to receive mentoring, attributing inspiration from the Project faculty and other Latino/a alumni. As her professional journey continues, she considers her belief and dedication to social justice a result of her experience with the collaborative gains made by the Project and the Latino community.

Leadership for community emancipation: partnership efforts. Project faculty maintain community participation through allying with and supporting Project alumni; and partnering with social service and governmental agencies, professionals and community activists in advocacy efforts that foster community emancipation. The following are examples of Project partnership efforts:

Escúchenos conference. The annual Escúchenos conference was conducted for eight consecutive years, originally organized by a group of child welfare and child advocacy community organizations, and led by Project faculty. The Escúchenos Conference was created to address the needs of Latino/a youth in the care of the state's Department of Children and Families (DCF). Escúchenos in English means: Listen to us. The conference had a non-traditional and unique format: youth presented their major foster placement concerns, while the adult professional audience, made up of DCF administrators, service providers and foster care policy-makers, listened to the issues and needs raised by the youth. The major goals of the conference included advocacy on behalf of Latino/a youth (their individual needs); affirmation of their cultural identity; and attention to the homogeneous DCF cultural climate through activities that celebrate the Latino/a culture such as the inclusion of Latino food and music, dialogues and presentations on culture, cultural identity, and affirmations about the strengths of the Latino culture. As a result of 
the conference proceedings, the recommendations were distributed to DCF, community agencies, and advocacy groups that could develop cultural activities and access to culturally sensitive services for Latino/a youth. In sum, the expressed need of the youth for a greater connection to their culture led DCF to implement the following culturallysensitive actions:

Quinceañera program. This program enables DCF Latina youth to participate in the long-honored Latino coming-of-age tradition for teenage girls, which includes a mentoring component and incentives for the Latina adolescent to succeed academically. The Quinceañera Program is intended to emphasize and develop cultural awareness, improve the girls' self-confidence and self-esteem, and encourage them to pursue higher education. The actual ceremony, clothes, and preparations for this event are paid for by DCF.

Ethnic hair and skin care policy. Latino/a youth are now able to receive culturally appropriate hair treatments or skin care maintenance. Products that may not be affordable or accessible to them or their foster care families are provided by DCF.

College tours. The Department's Bureau of Adolescent and Transitional Services have instituted the Hispanic Association of Colleges and Universities (HACU) tours. These tours are designed to introduce Latino/a youth to colleges whose student population is at least 25\% Latino/a (DCF, 2008). In effect, the Project's involvement in this community partnership gave an emancipatory leadership voice to foster children who ordinarily feel invisible and unheard.

Latino Voters' Campaign. Another example is the Project's two year involvement in the 2008 state-wide Latino Voters' Campaign initiative. In 2007, Project faculty, students, and alumni became involved in a State-sponsored summit to generate voter education and registration targeted to the Latino community. Over the next year, Project members, along with other grassroots committees operating in other states, took part in numerous grassroots efforts to register Puerto Ricans and other Latinos/as to vote.

In 2008, various voting campaign efforts hosted by L.A.S.O., the Project, and a school's Institute for Political Social Work were presented to the school's community and the university community in general to increase Latino/a political participation. This recruitment effort, led by a Latina student leader, galvanized the campaign's volunteer youths to register new voters on college campuses and in state-wide community summer events. In addition, on Election Day, the youth participated in door-to-door efforts to get individuals to vote and worked as volunteers at state-wide election polls. As a result of the campaign, the goal of registering 10,000 voters was doubled and 21,570 new Latino/a voters were registered. In short, Project partnerships foster and support indigenous community leadership, collaborate with key stake holders, and enlist and support grassroots community efforts that have a significant political impact.

Community Advocacy Groups. A third example has been the creation of community advocacy groups. One example is a grassroots community effort, initiated by a partnership of Project faculty, professionals, and community members, to address the needs, aspirations, and contributions of the Latina and Latino Lesbian, Gay, Bisexual, 
Transgender, Queer, and Intersexed (LGBTQI) population. This organization is meeting an important need in the Latino community as it strives to promote equality for Latinas/os and embraces social justice. This is the only organization in the state that is focused on achieving rights and opportunities for the Latino LGBTQI population. Examples of their accomplishments have been: participating in legislative hearings with government officials and press conferences on state issues affecting LGBTQI population; sponsoring fundraising events to advocate for and support LGBTQI community concerns; and sponsoring Latino cultural events that represent the strengths, realities, and talents of the LGBTQI community.

The above Project-community partnerships involve groups of leaders, many of which are current students and established Project Latino/a alumni leaders, leaders within the profession, political and geographical community leaders, and Project faculty. From these partnerships, new and established Latino/a leaders are now sitting on Advisory Boards, Commissions, and professional organizations at the local and national level; and contributing to an enhanced Latino community that serves the well-being of its members and other surrounding disenfranchised communities; hence, supporting Davis' (1997) claim that many of the most prominent Latino/a leaders credit their success to college or high school involvement in campaigns, protests, and service efforts to improve conditions for Latinos/as.

\section{Leadership Development for Community Emancipation: Replication Considerations}

In the context of this article, leadership development is defined as a collective collaborative, culturally-attuned, and transformative process between leaders and communities to achieve a change in targeted social problems. The authors propose the following institutional, faculty, and community emancipatory considerations when replicating the proposed educational leadership development approach for disenfranchised students and communities.

\section{Institutional Considerations}

1) Institutions must have a commitment to addressing the needs of disenfranchised and oppressed communities; 2) Institutions should be committed to developing culturally effective ways of recruiting and retaining Latino/a students; 3) Institutions must be committed to Latino/a leadership development. Such commitment can be demonstrated by the presence of a supportive infrastructure, e.g. the hiring of junior and senior Latino/a faculty and staff; office space, and administrative and support services; and 4) Institutions must support the development of a Latino community milieu through which leadership opportunities, mentoring, modeling, and emancipatory community partnerships occur.

\section{Faculty Considerations}

1) Faculty should pay attention to the leadership potential of its students of color, facilitate and advocate for leadership development opportunities; 2) Faculty need to

model leadership skills and support the importance of leadership development for the 
social work profession; faculty should remember that they are teaching by example. In this sense, the service component of a faculty member's workload acquires special meaning and value. 3) Faculty should consider that mentoring is an important component of the work done in academia and they should be willing to "build their own capacities as mentors and to advocate for institutional practices that support mentoring practice." (Gutierrez, 2012). In particular, faculty need to be committed to mentoring devalued student populations to become emerging leaders. This requires a time investment with consistent and continuous effort since it relies on relationship building, often a cultural imperative with devalued student populations. Among Latinos/as, such mentoring relationships need to be culturally-attuned to values such as personalismo, familismo, and Latino cultural traditions; and 4) Involvement in community emancipatory efforts for historically oppressed communities should be an individual and collective faculty commitment.

\section{Community Emancipation Considerations}

1) Collective and collaborative relationships of leaders should be developed within and outside of the disenfranchised community. These relationships should promote an exchange of ideas to create a shared communal vision; 2) The leadership activities should be culturally-attuned to the populations or communities they address, while also affirming their cultural identities; 3) Relationships between leaders and followers should be equitable, transforming their efforts to serve in the best interests of devalued and underrepresented communities; and 4) Indigenous community leadership should be fostered, and efforts to gain political and social equality for their respective communities should be supported.

\section{Future Research Considerations}

The Project's model has not been systematically evaluated. However, if it is to be replicated, the authors suggest that an evaluation component be added to test its validity and generalizability. In addition, the evaluation could examine the relationship between Project Latino/a alumni and their success as social work leaders. A comparative study of the similarities and differences between Project leaders and Latino/a leaders from mainstream social work programs is another necessary examination. Additional research could explore how ethnic group, acculturation, and gender differences among Latino/a leaders influence their work with the community.

In conclusion, the paper provides an integrative view of leadership development as a collective, culturally-attuned, transformative, and emancipatory process that can have a two-fold outcome:, successful educational Latino/a leadership development, and emancipation for Latino communities. The approach can be employed for other disenfranchised populations, as long as schools of social work create appropriate infrastructure and secure faculty commitments that create community milieus such as the one created by the School of Social Work's Project. Leadership development efforts should begin with students, by providing leadership opportunities, mentoring, and faculty modeling. The authors also assert that for the leadership approach to be complete, emancipatory partnerships in and with the disenfranchised community are necessary. As 
Cordero, Negroni/LEADERSHIP DEVELOPMENT FOR LATINO COMMUNITY EMANCIPATION 118

so aptly stated by Freire (1970) "The oppressed must be their own example in the struggle for their redemption” (p. 54).

\section{References}

Adams, M., Bell, L., \& Griffin, P. (2007). Teaching for diversity and social justice ( $^{\text {nd }}$ ed.). New York, NY: Routledge.

Ahsan, N. (2007). Evaluating leadership efforts for neighborhood transformation. In K. Hannum, J. W. Martineau, \& C. Reinelt (Eds.), Handbook of leadership development evaluation. ( $1^{\text {st }}$ ed., pp. 403-426). San Francisco, CA: Jossey- Bass \& Center for Creative Leadership.

Annie E. Casey Foundation. (2006). Leadership in action program final report. Baltimore, MD: Author. Retrieved from http://leadershiplearning.org/system/files/LAP_report_0.pdf

Bass, B. M. (1990). Bass and Stogdill's handbook of leadership ( $3^{\text {rd }}$ ed.). New York, NY: The Free Press.

Bass, B., \& Riggio, R. (2006). Transformational leadership ( $2^{\text {nd }}$ ed). Mawah, NJ: Lawrence Erlbaum Associates.

Ballesteros, D. (2007). Leadership always makes a difference. In L. Valverde (Ed.), Latino change agent in higher education: Shaping a system that works for all (pp. 193-214). San Francisco, CA: Jossey-Bass.

Bennis, W., \& Nanus, B. (1985). Leaders: Strategy for taking charge. New York, NY: Harper \& Row.

Bordas, J. (2001). Latino leadership: Building a humanistic and diverse society. Journal of Leadership and Organizational Studies, 8(2), 112-134.

Bordes, V., \& Arredondo, P. (2005). Mentoring first year Latino/a college students. Journal of Hispanic Higher Education, 4(2), 114-133.

Brabeck, M., Walsh, M., \& Latta, R. (Eds.) (2003). Meeting at the hyphen: Schoolsuniversities-communities-professions in collaboration for student achievement and well being. Chicago, IL: National Society for the Study of Education.

Burns, J. M. (1978). Leadership. New York, NY: Harper \& Row.

Burns, J. M. (2003). Transformative leadership: A new pursuit of happiness. New York, NY: Atlantic Monthly Press.

Cabrera, A., \& La Nasa, S. M. (Eds.) (2000). Understanding the college choice of disadvantaged students: New directions for institutional research. San Francisco, CA: Jossey-Bass.

Caravalho, J., \& Kayama, M. (2011). Education, identity and community: Lessons from Jewish emancipation. Retrieved from http://faculty.sites.uci.edu/jpcarv/files/2011/03/education-and-schism18.pdf 
Center for Ethical Leadership. (2009). Leadership for the 21st century: Crossing boundaries, strengthening communities. Battle Creek, MI. Author. Retrieved from http://ethicalleadership.org/programs/past-programs-1/publications-and-media1/21stCenturyLeadershipLQ.pdf

Chapa, J., \& De la Rosa, B. (2006) The problematic pipeline: Demographic trends and Latino participation in graduate science, technology, engineering and mathematics programs. Journal of Hispanic Education, 5(3), 203-221. doi: $10.1177 / 1538192706288808$

Collins, D., Weinbaum, A., Ramon, G., \& Vaughan, D. (2009). Laying the groundwork: The constant gardening of community-university-school partnerships for postsecondary access and success. Journal of Hispanic Education, 8(4) 394-417.

Collins, J. (2001). Level five leadership: The triumph of humility and fierce resolve. Harvard Business Review. Retrieved from http://www.tree4health.org/distancelearning/sites/www.tree4health.org.distancelearni ng/files/readings/Collins.\%20Five\%20Leadership\%20Levels.pdf

Cooper, R., \& Liou, D. D. (2007). The structure and culture of informative pathways: Rethinking opportunity to learn in urban high schools during ninth grade transition. High School Journal, 91(1), 43-56.

Cordero, A. (2008). Towards competency with a Latino community: A cross-cultural teaching model. Journal of Teaching in Social Work, 28(1/2), 165-189.

Cordero, A., \& Negroni, L. (2009). Fostering cross-cultural learning and advocacy for social justice through a cultural immersion experience in Puerto Rico. Journal of Teaching in Social Work, 29(2), 134-152.

Council on Social Work Education. (2012) Leadership Institute. Retrieved from http://www.cswe.org/CentersInitiatives/CSWELeadershipInst.aspx

Davis, M. (1997). Latino leadership development: Beginning on campus. National Civic Review, 86(3), 227-233.

Deil-Amen, R., \& Turley, R. (2007). A review of transition to college literature in sociology. Teachers College Record, 109(10), 2324-2366.

Enright, K. P. (2006). Investing in leadership volume 2: Inspiration and ideas from philanthropy's latest frontier. Washington, DC: Grantmakers for Effective Organizations. Retrieved from http://www.philanthropynw.org/s_pnw/bin.asp?CID=17249\&DID=43456\&DOC=FI LE.PDF

Erisman, W., \& Looney, S. (2007). Opening the door to the American dream: Increasing higher education access and success for immigrants. Washington, DC: Institute for Higher Education Policy. Retrieved from http://www.ihep.org/assets/files/publications/m-r/OpeningTheDoor.pdf 
Excelencia in Education. (2012) Ensuring America's future by increasing Latino college completion rates: Latino college completion rates in 50 States. Retrieved from http://www.edexecelencia.org/eaf/50states

Farooqui, M. (2012). Education is the key to community emancipation. Retrieved from http://twocircles.net/2012jun24/\%E2\%80\%98education_key_community_emancipati on\%E2\%80\%99.html

Freire, P. (1970). Pedagogy of the oppressed. New York, NY: Continuum.

Freire, P. (1974). Education for critical consciousness. New York, NY: Continuum.

Foster, W. (2005). Toward a critical practice of leadership. In J. Smyth (Ed.), Critical perspective on educational leadership (pp. 27-42). New York, NY: Taylor \& Francis.

Gauthier, A. (2006). Developing collective leadership: Partnering in multi-stakeholder contexts. In A. Gauthier, W. Link, T. Corral, \& M. Gerzon (Eds.), Leadership is global (pp.1-20). San Francisco, CA: Shinnyo-en Foundation.

Giroux, H. (1992). Border crossings: Cultural workers and the politics of education. New York, NY: Routledge.

Goldrick-Rab, S., Cater, D., \& Wagner, R (2007). What higher education has to say about the transition to college. Teachers College Record, 109(10), 9-10.

Greenleaf, R. K. (1977). Servant leadership: A journey into the nature of legitimate power and greatness. New York, NY: Paulist Press.

Griffin, P., \& Ouellett, M. L. (2007). Facilitating social justice education courses. In M. Adams, L. A. Bell, \& P. Griffin (Eds.), Teaching for diversity and social justice $\left(2^{\text {nd }}\right.$ ed., pp. 89-113). New York, NY: Routledge.

Gutierrez, L. (2012). From the editor: Recognizing and valuing our roles as mentors. Journal of Social Work Education, 48(1), 1-4.

Henrickson, R. L. (1989). Leadership and culture. (Unpublished doctoral dissertation, University of San Diego, California).

Hubbard, B. (2005). Investing in leadership volume 1: A grantmaker's model for understanding nonprofit leadership development. Washington, DC: Grantmakers for Effective Organizations. Retrieved from http://geofunders.org/geo-publications/582leadership-volume-1

Joiner, B., \& Josephs, S. (2007). Leadership agility: Five levels of mastery for anticipating and initiating change (1st ed.). San Francisco, CA: Jossey-Bass.

Jordan, A. (2006). Tapping the power of social networks: Understanding the role of social networks in strengthening families and transforming communities. Baltimore, MD: Annie E. Casey Foundation.

Kane, C. (1998). Differences in family of origin perceptions among African Americans, Asian Americans and Hispanic American college students. Journal of Black Studies, 29(1), 93-195. 
Kellerman, B. (2004). Bad leadership: What it is, how it happens, why it matters. Boston, MA: Harvard Business School Press.

Leadership Learning Community. (2010). Leadership for a new era series: A new leadership mindset for scaling social change. Retrieved from www.leadershipforanewera.org.

Leon. D., \& Nevarez C. (2007) Models of leadership institutes for increasing the number of top Latino administrators in higher education. Journal of Hispanic Higher Education, 6, 356-377. doi: 10. 1177/1538192707305344

Louie, V. (2007). Who makes the transition to college? Why we should care, what we know and what we need to know. Teachers College Record, 109(10), 2-3.

Luna, V., \& Prieto, L. (2012). Mentoring affirmations and interventions: A bridge to graduate school for Latina/o students. Journal of Hispanic Higher Education, 8(2), 213-224.

Manoleas, P., \& Carrillo, E. (1991). A culturally syntonic- approach to the field education of Latino students. Journal of Social Work Education, 27(2), 135-144.

McGonagill, G., \& Pruyn, P. (2010). Leadership development in the U.S.: Principles and patterns of best practice. Retrieved from: http://www.mobiusleadership.com/resources/Leadership_Development_in_the_US_Best_Practice-TD\%2020jan10_FINAL.pdf

McGonagill, G., \& Reinelt, C. (2011). Leadership development in the social sector: A model for supporting strategic investments. The Foundation Review, 2(4), 57-72.

McKensie, B., Christman, D., Hernandez, E., Fierro-Capper, C., Dantley, M., \& Scheurich, J. (2008). From the field: A proposal for educating leaders for social justice. Educational Administrative Quarterly, 44(1), 111-138. doi: 10.1177/0013161X07309470

McWhirter, E., Torres, D., Salgado, S., \& Valdez, M. (2007). Perceived barriers and postsecondary plans in Mexican American and White adolescents. Journal of Career Assessment, 15(1), 119-138. doi: 10.1177/1069072706294537

Meehan, D., \& Reinelt, C. (2006). Accelerating learning about leadership development: A learning community approach. Handbook of Leadership Development Evaluation. San Francisco, CA: Jossey-Bass Publishers.

Miller, S., \& Garcia, E. (2004). Better informing efforts to increase success in higher education. Education and Urban Society, 36(2), 189-204.

Mogros-Wilson, C. (2011). Resilience in vulnerable and at risk Latino families. Infant and Young Children, 24(3), 267-279. doi: 10.1097/IYC.0b013e31822006b2

Molloy, P., \& Elis, R. (2006). Leadership as the management of process and culture: An integrated model. Sidney Australia: University of Sydney. Retrieved from http://www.aquarico.com/webstorage/Publications/Uni\%20Syd\%20Working\%20Paper\%20Oct\%2095.pdf 
National Association of Social Workers. (2010). Social work imperatives for the next decade. Adopted at the 2010 Social Work Congress in Washington, DC. Retrieved from http://www.socialworkers.org/2010congress/documents/2010Imperatives.pdf

Negroni-Rodriguez, L., Dicks, B., \& Morales, J. (2006). Cultural considerations in advising Latino/a students. Journal of Teaching in Social Work, 26(1/2), 201-221.

Negroni-Rodríguez, L. K., \& Morales, J. (2001). Individual and family assessment skills with Latino/Hispanic-Americans. In R. Fong \& S. Furuto (Eds.), Culturally competent practice: Skills, interventions, and evaluations (pp. 132-146). Boston, MA: Allyn and Bacon.

Northouse, P. (2009). Leadership and theory. Oakland, CA: Sage Productions.

Nunez, A., \& Carroll, C. (1998). First-generation students: Undergraduate students whose parents never enrolled in post-secondary education. Washington, DC: National Center for Educational Statistics. Retrieved from http://nces.ed.gov/pubs98/98082.pdf

Oliva, M. (2008). Latino access to college: Actualizing the promise and potential of K-16 partnership. Journal of Hispanic Higher Education, 7(2), 119-130.

Omotoso, S. (2010). Education and emancipation: An African philosophical perspective. The Journal of Pan African Studies, 3(9), 222-231.

Pachon, H., \& Moore, J. (1981). Mexican American. Annals of the American Academy of Political and Social Scientists, 454(1), 111-124.

Perna, L. (2006). Differences in the decisions to attend college among African American, Hispanics, and Whites. Journal of Higher Education, 71(2), 117-141.

Pew Research Center (2008). U.S. Population Projections: 2005-2050. Retrieved from http://www.pewhispanic.org/2008/02/11/us-population-projections-2005-2050/

Plastrik, P., \& Taylor, M. (2010). Network power and philanthropy and nonprofits. Retrieved from http://www.barrfoundation.org/files/Netork_Power_for_Philanthropy_and_Nonprofit s.pdf

Post, D. (1990). College-going decisions by Chicanos: The politics of misinformation. Educational Evaluation and Policy Analysis, 12(2), 174-187.

Ramirez, A. (2006). Hispanic leadership development and its policy impact. Harvard Journal of Hispanic Policy, 18, 85-89.

Reinelt, C., Yamashiro-Omi, D., \& Meehan, D. (2010). Learning-circle partnerships and the evaluation of a boundary-crossing leadership initiative in health. The Foundation Review 2(1), 40-52.

Rivera-Goba, M. V., \& Nieto, S. (2007). Mentoring Latina nurses: A Multicultural perspective. Journal of Latinos \& Education, 6(1), 35-53. 
Rodriguez, R., \& Villarreal, A. (2001). Transformative leadership in Latino communities: A critical element in successful and sustainable educational change. Retrieved from http://www.idra.org/IDRA Newsletter/June -

_July_2001_Self_Renewing_Schools_Changing_Student_Population/Transformative Leadership_in_Latino_Communities/

Rojas-Schwan, N., Negroni, L. K., \& Santiago, A. (October, 2012). Developmental relationships among Latina/o social workers to foster career advancement. Paper presented at the Annual National Mentoring Conference. University of New Mexico, Albuquerque, NM.

Rourke, B. (2006). Prevailing in the long run: New leaders and new structures spur action on poverty. St. Paul, MN: Northwest Area Foundation. Retrieved from http://www.bradrourke.com/wp-content/uploads/2009/09/Prevailing-in-The-LongRun-Report.pdf

Saenz, V., Hurado, S., Barrera, D., Wolf, D., \& Yeung, F. (2007). First in my family: A profile of first generation college students at four-year institutions since 1971. Los Angeles: UCLA Higher Education Research Institute. Retrieved from http://www.heri.ucla.edu/PDFs/pubs/TFS/Special/Monographs/FirstInMyFamily.pdf

Schein, E. (1985). Organizational culture and leadership. San Francisco, CA: JosseyBass.

Sheafor, B. (2006). Leadership development initiative report. Unpublished Manuscript. Retrieved from http://www.cswe.org/File.aspx?id=22221

Senge, P. M., Smith, B., Kruschwitz, N., Laur, J., \& Schley, S. (2008). The necessary revolution: How individuals and organizations are working together to create a sustainable world. New York, NY: Doubleday, Currency.

The California Endowment. (2006). A conversation on boundary-crossing leadership. Los Angeles, CA: Author. Retrieved from http://www.calendow.org/uploadedFiles/conversation_on_boundary-crossing.pdf

Teranishi R., \& Briscoe,K (2006). Social capital and racial stratification of college opportunity. Higher Education: The Handbook of Theory and Research, 21, 591-614.

Tooms, A., \& Boske, C. (Eds.) (2010). Bridge leadership: Connecting educational leadership and social justice to improve schools. Charlotte, NC: Information Age Publishing.

U. S. Census Bureau. (2011a). Selected Population Profile in the United States: 2011 American Community Survey 1-year Estimate (S0201). Retrieved from http://factfinder2.census.gov/faces/nav/jsf/pages/index.xhtml

U. S. Census Bureau. (2011b). Income, Poverty and Health Insurance in the United States: 2011Current Population Reports. (P60-243). Retrieved from http://www.census.gov/prod/2012pubs/p60-243.pdf 
U. S. Census Bureau. (2011c). Selected Population Profile in the United States: 2011 American Community Survey 1-year Estimate (S0201). Retrieved from http://factfinder2.census.gov/faces/nav/jsf/pages/index.xhtml

U. S. Census Bureau. (2011d). Selected Population Profile in the United States: 2011 American Community Survey 1-year Estimate. (S0201). Retrieved from http://factfinder2.census.gov/faces/nav/jsf/pages/index.xhtml

U. S. Department of Labor. (2011). Labor force characteristics by race and ethnicity, 2011 (1032). Retrieved from http://www.bls.gov/cps/cpsrace2010.pdf

W. K. Kellogg Foundation. (2004). Building leadership for the 21st century: A report from Global Leadership Scans. Battle Creek, MI: Author. Retrieved from http://www.wkkf.org/knowledge-center/resources/2004/09/building-leadership-forthe-21st-century-a-report-from-global-leadership-scans.aspx

W. K. Kellogg Foundation. (2006). Crossing boundaries, changing communities: Lessons in collective leadership. Battle Creek, MI: Author. Retrieved from http://www.wkkf.org/knowledge-center/resources/2006/04/crossing-boundarieschanging-communities-lessons-in-collective-leadership.aspx

\section{Author note}

Address correspondence to: Antonia Cordero, Ph.D., Associate Professor, University of Connecticut, School of Social Work, 1798 Asylum Ave., West Hartford, CT 06117.

Email: antonia.cordero@uconn.edu 